\title{
Research Trends in Digital Technologies and Modeling in Mathematics Education
}

\author{
Juan Fernando Molina-Toro ${ }^{1 *}$, Paula Andrea Rendón-Mesa ${ }^{2}$, Jhony Alexander Villa-Ochoa ${ }^{2}$ \\ ${ }^{1}$ Master in Mathematics Education. Mathematics Education Area, Universidad de Antioquia, COLOMBIA \\ ${ }^{2}$ Doctor in Education. Mathematics Education Area, Universidad de Antioquia, COLOMBIA
}

Received 22 November 2018 • Revised 18 February 2019 • Accepted 3 March 2019

\begin{abstract}
This document presents a literature review that analyzes the articulation of modeling and digital technologies in the field of Mathematics Education. The review aims to find evidence of the use of digital technologies in modeling processes and how these practices can change some ways of working with students in the classroom. The results show, on the one hand, different roles that technology plays when it is articulated to a modeling process (as a resource in the process or as a means that reorganizes the process) and the uses given to diverse technological tools in the empirical studies analyzed. The findings present a new category that extends the classification of technologies and suggest the need to expand both theoretical and empirical research to get a better understanding of the impact of digital tools in modeling processes. In addition, the findings draw attention to the inclusion of mobile devices in future studies.
\end{abstract}

Keywords: mathematics education, modeling, digital technologies

\section{INTRODUCTION}

Modeling is a research domain within Mathematics Education with a high degree of consolidation in the last three decades (Blum, Galbraith, Henn, \& Niss, 2007, Frejd, 2013). Academic events, communities, books series and specialized journals in the subject are some of the evidences of this fact. The study of modeling (used instead of mathematical modeling in Mathematics Education) can be justified by its contributions to the mathematical work in the classroom, the investigative skills it promotes and the possibilities of establishing links between reality and mathematics it generates (Blum \& Borromeo Ferri, 2009).

At the international level, modeling research has a diversity of approaches and perspectives both for research and for its development in the classroom (Kaiser \& Sriraman, 2006, Villa-Ochoa, Castrillón-Yepes, \& SánchezCardona, 2017). Other research offers evidence that analyzes the development of modeling processes, the roles assumed by students and teachers, and the means and resources that constitute a modeling practice (Lingefjärd \& Meier, 2010; Pereira \& Júnior, 2013). Other research offers evidence of a close relationship between modeling and technology, and how it has an effect on students learning (Neves \& Teodoro, 2014, Soares \& Borba, 2014, Trigueros, 2009).

In the literature, modeling and digital technologies interact as two fields of research with specific emphasis and purpose, although not always converging with each other. In an integrating vision, the articulation between modeling and technology could be approached in two different ways. The first one is related to a set of studies that analyze methodological and theoretical aspects of modeling processes. Studies in this field present class episodes where students construct mathematical models to solve problems, validate models with the help of software and construct graphic representations to interpret the situation under study (Possani, Trigueros, Preciado, \& Lozano, 2010; Stillman, 2011; Villa-Ochoa, González-Gómez, \& Carmona-Mesa, 2018).

(C) 2019 by the authors; licensee Modestum Ltd., UK. This article is an open access article distributed under the terms and conditions of the Creative Commons Attribution License (http://creativecommons.org/licenses/by/4.0/). \juan.molinat@udea.edu.co juanfdomolina@gmail.com (*Correspondence) $\square$ paula.rendon@udea.edu.co 凹jhony.villa@udea.edu.co 


\section{Contribution of this paper to the literature}

- Although previous studies show that the use of technology can condition the development of modeling processes, it is necessary to identify the scope and limitations of its articulation in the analysis of various phenomena.

- This literature review provides evidence of the roles and uses of technology when articulated to modeling processes. On the one hand, technology is used as a resource in which multiple tools that accompany the study of a phenomenon are involved. On the other hand, technology is an instrument that reorganizes the processes of experimentation and the production of mathematical knowledge.

The second approach attends to studies that focus on transcending "domesticated" 1 or simply figurative uses of the interrelation between modeling and technologies. In this vision, technology is assumed as a fundamental component in the reorganization of the ways of doing modeling and generating knowledge through the process. (Borba \& Villarreal, 2005; Diniz \& Borba, 2012).

These two points of view produce different guidelines for the development of modeling; On the one hand, there are studies that integrate technology to a conventional way of viewing modeling as a process. On the other, there are studies in which technology reorganizes such processes and also the way of understanding modeling.

In addition to these two approaches and to the perspectives and ways of understanding modeling, there is a wide variety of positions regarding the contributions of modeling with digital technologies and its impact on student learning. In cognitive approaches, learning is oriented to the development of skills and comprehension of mathematical objects (Blum \& Borromeo Ferri, 2009; Stillman, 2011). In critical approaches, learning is oriented towards students' need to develop mathematical views articulated with phenomena and contexts of their environment and towards the use of mathematics in the exercise of responsible citizenship (Diniz \& Borba, 2012; Soares \& Borba, 2014).

In a previous study, Pereira, Seki, Palharini, Neto, Silva, Damin and Martins (2017) identified the contributions of multiple technologies to modeling processes and found evidence of how computer programs are used as a support for the coordination of different representations of mathematical objects and the construction and analysis of mathematical, graphical and algebraic models that are linked to reality through virtual environments. The authors state that the use of digital technologies in mathematical modeling promotes participation and discussion among students, favors their motivation and facilitates the learning of mathematics.

The above mentioned facts show a close relationship between modeling and digital technologies and their impact on student learning that goes beyond the presentation of concepts, mathematical algorithms or training processes. In line with this, recent research recognizes the contributions, changes and reorganization of mathematics-teaching processes when modeling and technology are linked (Greefrath \& Vorhölter, 2016; Soares \& Borba, 2014; Villa-Ochoa et al., 2018).

New technological developments and their impact in society generate new demands and dynamics in the classroom both for those who assume technology as a tool that can be articulated to modeling processes, and for those who consider it as a means to reorganize the production of knowledge and modeling itself. The literature shows research that, under these two approaches, emphasizes ways to develop modeling processes (for example, Daher \& Shahbari, 2015; Molina-Toro, 2013; Trigueros, 2009). However, research is required that offers empirical evidence of the contributions that new ways of reorganizing modeling processes with technologies offer to the teaching and learning of mathematics. Likewise, broader and deeper knowledge is required in order to establish integrative relationships between different types of technologies and multiple ways in which modeling processes are implemented in Mathematics Education.

New digital tools are generating new functionalities of technology in modeling processes, that is, new roles that do not depend only on the use of the devices. In coherence with the aforementioned approaches, this review presents the results of a study that investigates the ways in which the international literature interprets the relationship between modeling and technology. In particular, the study was guided by the following questions:

What roles do digital technologies assume when they are integrated into modeling processes in Mathematics Education? What uses do digital technologies have within those processes?

To answer those questions, a study was developed under a critical approach to literature. The method, results and conclusions make up each of the three sections that follow in this article.

\footnotetext{
${ }^{1}$ According to Borba and Villareal (2005), technology is 'domesticated' when it is utilized to do what we were used to do by other means, ignoring or wasting other potential uses.
} 


\section{METHODOLOGY}

In coherence with Jesson and Lacey (2006), a literature review is a narrative of the information that relates different perspectives or paradigms and reflects the point of view of the person who constructs it. Its objective is to present an evaluation of previously published information and, in that way, to present what is known about a particular topic and to identify a possible knowledge gap that may extend a field of research. As previously mentioned, this review seeks to find empirical evidence of the different roles and uses given to digital technologies when they are integrated into modeling environments, such as aspects related to the learning of mathematical contents, skills, processes, recognition of the role of models and mathematics in society, among others.

\section{Criteria for Searching and Selecting Material}

In coherence with the topics of interest of this review, an information search was initially carried out in the Scopus database 2 . The keywords "Modelling" AND "Mathematics Education" AND "Classroom" were used as a search query. The search process returned 48 articles for analysis. When changing the term "Modelling" to "Modeling", an additional record was obtained. In order to ensure a study over recent research, a filter was made to get articles published in the last 10 years, which yielded a list of 32 documents. Texts written in English, Spanish and Portuguese were favored.

Each document was assessed taking into account if: (a) the title was related to modeling topics, (b) the document included the use of digital technologies in its proposal (c) the abstract offered information about an empirical work reporting the use of technology and modeling in mathematics. To avoid publication bias (Jesson \& Lacey, 2006), the first four volumes of the book series International Perspectives on the Teaching and Learning of Mathematical Modeling in Springer and ICME-13 Topical Survey on Modeling (Greefrath \& Vorhölter, 2016) were included into the study. In those books, the selected chapters were identified through the word "Technology".

Subsequently, each document was read in order to identify i) roles of digital technologies in modeling processes and ii) uses of digital tools integrated to those processes. The reading of those documents suggested the inclusion of other documents that extensively developed the central theme of the review. The inclusion of new documents took into account, on the one hand, the impact of the journals, which, without being in the database that served as a reference, have many widely-disseminated investigations in Mathematics Education. On the other hand, works referenced in primary documents were included, allowing us to have a better interpretation of the positions of their authors.

In total, 29 journal articles, 12 book chapters and one book were analyzed.

\section{Information Analysis}

The analysis of the compiled articles was developed in two phases. Initially, the documents were attached to the Atlas.ti software. Two codes were created to delimit main categories a priori (a) Roles of modeling technologies and b) Uses of digital technologies in modeling processes. The coding in the Atlas.ti software looked to group theoretical and empirical topics related to modeling, use of technology and ways in which they assume and characterize students' learning.

In each document, the roles of digital technologies were identified; to do this, we focused on: recognizing the type of devices used (sensors, computers, mobile devices, among others), the way they intervened in the development of the processes and the needs that were met with their implementation. To identify the uses of technologies in those processes, we focused on recognizing what the devices were used for during student practices when developing the modeling process (taking data, performing calculations, graphing, among others).

As suggested by Jesson and Lacey (2006), criteria (components, in this case) and new codes to organize citations in the documents, were created. The citations were classified into theoretical and empirical, taking into account their relationship to the guiding questions and categories of the review. The coding, in addition to grouping the works, allowed to establish criteria of comparison among the various ideas found inside each document. It also generated possible questions for future research.

Table 1 shows the categories that were defined a priori for the analysis of the documents and the questions that established the analysis criteria. The components were emerging elements in the review.

\footnotetext{
${ }^{2}$ The search was made using the access platform to databases of the University of Antioquia in February 2016
} 
Table 1. Categories that guided the analysis of documents

\begin{tabular}{|c|c|c|}
\hline Category & Components & Criteria of analysis \\
\hline \multirow{3}{*}{$\begin{array}{l}\text { Roles of } \\
\text { technology in } \\
\text { modeling } \\
\text { processes }\end{array}$} & & \\
\hline & development of modeling processes. & s configured? \\
\hline & Technology as a reorganizer of the & How are modeling processes modified when including technologies? \\
\hline $\begin{array}{l}\text { Uses of digital } \\
\text { technologies in } \\
\text { modeling } \\
\text { processes }\end{array}$ & $\begin{array}{l}\text { Uses of digital tools that are } \\
\text { integrated into modeling processes }\end{array}$ & $\begin{array}{l}\text { What uses does technology have within the performed modeling } \\
\text { processes? } \\
\text { What do students use technologies for? } \\
\text { What effects did technology have in the development of the processes? }\end{array}$ \\
\hline
\end{tabular}

\section{RESULTS}

Each document was analyzed based on the questions that guided the review and the categories and criteria presented in Table 1. The main findings of this study are presented below.

\section{Roles of Technology in Modeling Processes}

Modeling and digital technologies represent two strong trends in international research in Mathematics Education. Modeling, on the one hand, is a way to integrate mathematics with other sciences and with "reality" (Krekic \& Namestovski, 2009; Rendón-Mesa, 2016; Villa-Ochoa, 2007). Modeling invites us to go beyond content development or to look at reality as an excuse to introduce topics or illustrate potential applications of mathematics (Villa-Ochoa \& Berrío, 2015). Also, modeling can be assumed as a dynamic process in which students and teachers intervene to formulate hypotheses, define variables, collect data, deduce mathematical models and verify their validity.

There is a tendency to include modeling approaches in curricula throughout the world (Blum, 2011). However, modeling is a task that demands challenges for students and teachers due to the multiple processes that it implies within the classrooms. Particularly complex are cases in which the impact of digital technologies and curricular integration are considered.

Digital technologies, on the other hand, play some roles in the modeling process associated with the possibility of developing experiments and simulations and promoting diverse kinds of participation of students in the construction of their own knowledge (Buteau, Muller, Marshall, Sacristán, \& Mgombelo, 2016; Kaiser, 2005; MolinaToro, 2013; Pons \& Espinosa, 2015). Technologies also provide numerical solutions, visualization and graphic control tools, as well as access to information on the web (Greefrath \& Vorhölter, 2016). The experiences that were presented in the work by Borba and Villarreal (2005) are a sample of how technologies reorganize the way of producing knowledge. This reorganization is not only considered as a different way to develop processes of mathematical knowledge production, but also as an alternative way of conceiving that knowledge.

As indicated above, there is no homogeneous understanding of the concept of mathematical modeling or its epistemological and didactic foundations (Kaiser \& Sriraman, 2006). Under this premise, different understandings of modeling should reflect different roles of technologies; that is, there may be a correspondence between the role of the used technology and the nature of the modeling process developed in the classroom.

In the following paragraphs, two categories emerging from the role of technologies in modeling processes are presented. Their epistemological points of view are not necessarily complementary.

\section{Technology as a resource for the development of modeling processes}

A trend in research in mathematical modeling focuses on recognizing the sub-processes involved in it. To do this, phases are described that intervene in the connection of two domains, one called mathematical and the other extra-mathematical, also called reality. Overall, the modeling process originates from a real-life problem (Blum et al., 2007; Greefrath \& Vorhölter, 2016; Perrenet \& Zwaneveld, 2012). This problem, commonly located in an extramathematical domain or in the "real world", is simplified in such a way that it can be represented with a model in the mathematical domain. Subsequently, the mathematical model is refined, interpreted and validated in light of the initial situation; these phases constitutes a modeling cycle (Blum et al., 2007).

This conception of modeling has been represented by researchers as different cycles. Some differences between representations lie in the emphasis given to sub-processes or actions of students (Perrenet \& Zwaneveld, 2012). Some examples of representations can be found in the works of Blum and Leiss (2007), Greefrath and Vorhölter (2016), Stillman and Brown (2014), and Perrenet and Zwaneveld (2012). In particular, the modeling cycle proposed 
by Blum and Leiss (2007) has been used by other authors to investigate what type of variations occur when technologies are linked to modeling processes (Daher \& Shahbari, 2015; Geiger, 2011; Greefrath, 2011)

In the work of Greefrath, Siller and Weitendorf (2011), examples of situations that allow analyzing the influence of technology in the modeling cycle are presented. The authors consider that technological tools do not only appear as a "third domain" to configure a model with complex formulas, structures and interpretations. Beyond that, they consider that technology influences each part of the cycle and is not limited to reducing the operating load to obtain results of numerical calculations or to make visual representations and transform data.

From a different point of view, Daher and Shahbari (2015) conceive technology as a bridge that communicates the 'real world' and the world of mathematics in different phases of the modeling cycle. For the authors, the diversity of links between technology and modeling emerges from the particular moments in which technology plays a role based on the use attributed to it by those who are modeling. In his representations of the modeling cycle, technology has a dynamic role that gives shape to the modeling process. For Daher and Shahbari, there is a relationship between the technological knowledge of the modeler and the way to integrate it in the cycle. For example, when people who model have a broad technological knowledge, the articulation of technology to the modeling processes can occur at several stages of the teaching process: while interpreting the phenomenon, when variables are characterized, when a translation into the technological medium is performed, etc.

The studies of Greefrath et al. (2011), Daher and Shahbari (2015), and Rodríguez and Quiroz (2016) integrate technologies into the modeling process. Those studies show that technologies can intervene in different phases and sub-processes of the cycle; thus, for Greefrath et al. (2011) technology can be used to calculate, measure and experiment in the mathematical work phase. Rodríguez and Quiroz (2016) show that technology is used for different purposes in different phases; for example, at the beginning of the modeling process, it is used to configure the study problem (for instance: analysis of a resistive-capacitive circuit with voltage sensors, computers, batteries, resistors and capacitors); subsequently, technology is used to build models supported by graphs and tables; finally, technology allows students to confront each of the results they have produced at different times in the modeling process.

Although Greefrath et al. (2011) and Daher and Shahbari (2015) integrate technologies into modeling processes, they do not substantially transform the understanding of modeling as a cycle; that is, the modeling process remains structurally the same, only the ways of doing sub-processes are modified (numerical calculations, representations, validations, among others). This tendency could be derived from the type of modeling tasks and formulations offered to students. Even if those modeling formulations involve a context or a phenomenon, the necessary information is commonly given in the wording of the modeling situation, can be found on the Internet or can be deduced by the understanding of the proposed situation. Consequently, the type of problem discussed does not require important uses of technology in the modeling process, such as in the case of experimental data collection proposed Rodríguez and Quiroz (2016).

The work of Geiger (2011), with a different orientation, adapting its scheme from the work of Galbraith, Renshaw, Goos and Geiger (2003), shows that the influence of technology is present in all of the stages of the modeling cycle. This orientation emerges from the author's consideration that the influence of technology in the modeling cycle is situational, that is, technology incorporation criteria depend on the circumstances and beliefs about technology of the teacher, regardless of the technological environment used. This point of view, although does not intend to establish generalities, shows that technology does not limit the multiple possible ways in which a modeling process can be developed, nor the ways in which technology and modeling can be put together.

Even though the above studies show different uses of technologies according to the phases or stages of the modeling cycles, it can be observed, as already mentioned, that the understanding of modeling as a process remains structurally the same. For example, in Blum and Leiss (2007), the modeling process is structured through six phases: real situation and problem, model of the situation, real model and problem, mathematical model and problem, mathematical results and real results. In coherence with this structure, in the described studies, the presence of technology enriches this view of the modeling cycle.

In the ways of presenting technologies in the modeling cycle, Blum and Leiss (2007) integrate different tools at particular moments in which they can contribute to the process; that is, calculation tools will be used to calculate, visualization tool are used to represent. Consequently, technology appear sometimes as elements that are external to the modeling process and to the modelers. This kind of stance seems to classify technology according to what it can do or promote. Works with different views are presented in the following section.

\section{Technology as a reorganizer of the modeling process}

In this category, modeling is conceived as a learning environment in which students participate according to their interests or needs (Borba \& Villarreal, 2005; Campos \& Araújo, 2015; Parra-Zapata \& Villa-Ochoa, 2016); processes are not previously established but emerge depending on the type of problem, the variables involved and 
Table 2. Roles assumed by digital technologies in modeling processes

\begin{tabular}{|c|c|c|}
\hline Category & Roles & Examples \\
\hline \multirow{2}{*}{$\begin{array}{l}\text { Roles of } \\
\text { technology in } \\
\text { modeling } \\
\text { processes }\end{array}$} & $\begin{array}{l}\text { Technology as a resource for the } \\
\text { development of modeling processes }\end{array}$ & $\begin{array}{l}\text { (Daher \& Shahbari, 2015; Greefrath et al., 2011; Perrenet \& Adan, } \\
\text { 2010; Possani et al., 2010; Rodríguez Gallegos \& Quiroz Rivera, } \\
\text { 2016; Stillman \& Brown, 2014; Trigueros, 2009) }\end{array}$ \\
\hline & $\begin{array}{l}\text { Technology as a reorganizer of the modeling } \\
\text { process }\end{array}$ & $\begin{array}{l}\text { (Borba, Villarreal, \& Soares, 2016; Molina-Toro \& Villa-Ochoa, } \\
\text { 2013; Soares \& Borba, 2014) }\end{array}$ \\
\hline
\end{tabular}

the relevant contexts for the student. Under this view, technology appears as a way to meet the needs that arise throughout the processes: obtain and analyze data, create a context or simulation of a phenomenon, compare models and results, validate or spread a model, etc.

In this view, technology is conceived as a non-neutral aspect neither in the learning nor in the process that students develop. In short, technology reorganizes the modeling process in the school setting. As an example, the modeling process of Geiger (2011) shows that technology gave rise to interpretations and discussions of the phenomenon of study that later promoted decision making and validation of the mathematical model using the digital resource. In this sense, students can, using technology, tackle more complex problems in which mathematical knowledge is not a limitation for their study.

Another aspect to consider is the possibility that students have to dialogue about the representations they obtain from different software. Software programs allow the introduction of data to make decisions with regard to a specific process, permit the change of numerical ranges in parameters and variables of dynamic objects and, additionally, can generate discussions and dialogues about mathematical objects and technology itself (Perrenet \& Adan, 2010).

These considerations evidence the various ways in which digital technologies contribute to the dynamics within the modeling process, generate conditions that reorganize it and allow students and professors to perform processes in a non-linear and flexible manner. In some cases, participants in modeling processes generate discussions based on mathematical models that they build through digital technologies; in others cases, they work with technologic tools from the moment they start the modeling process until they complete it.

The studies of Molina-Toro and Villa-Ochoa (2013) and Soares and Borba (2014) used technologies as a means to reorganize the modeling process and the model analysis, respectively; In those works, the students developed the modeling process based on particular interests of the phenomenon under study. They used the software 'Modellus' to let students handle variables, graphs and mathematical-model variables in a technological environment, so they could characterize movements or trends in the phenomenon under study. The authors support the idea that without the use of the software tool it would be very complex for students to analyze and compare results, contrast the choice of one model or another produced by their peers and, in addition, produce knowledge collectively.

In those studies, the software was not only a platform for occasional use, but became a central actor of the interaction process among students and facilitated the dialogue, the distribution of work and the possibility of obtaining feedback of the process. These works consider experimentation as an environment where students can mold the phenomenon and the process to be studied; for example, the can analyze pre-established models or project trends, compare them to their actual situation and propose a suitable model. Table 2 shows the two roles of digital technologies that were found in modeling processes.

In this section, two ways in which technological tools are integrated into modeling processes were presented. Both views attended to the roles (resource or reorganizer) that technologies assume within the modeling processes. They also focused on the phenomena that were addressed for their development and the theoretical orientations that accompanied their proposals. The following section presents various uses of digital technologies that were identified in those processes when analyzing the documents of this review.

\section{Uses of Digital Technologies in Modeling Processes}

Some papers analyzed in this review recognize the changes that technology promotes in human cognition (Blum, 2015; Diniz \& Borba, 2012) and also the possibility of making clear what students know and what they are learning (Greefrath, 2011; Possani et al., 2010). Lingefjärd and Meier (2010) for example, argue that the interaction between students, teachers and technologies generate ways to unblock students' ideas.

Researchers such as Greefrath (2011) call attention to the importance of having criteria to perform modeling tasks with the use of digital tools while promoting the learning of mathematics. That fact presupposes a broad knowledge of the characteristics of the technological instruments used. In this regard, Stillman and Brown (2014) declare that at some point, students must be able to anticipate the ways in which the instruments should be used 
to answer the posed questions. Below there are some uses that digital technologies assume when they are integrated into modeling processes.

\section{Uses of digital tools that are integrated into modeling processes}

The results of this study show different tools that are used in modeling processes. In coherence with Barzel et al. (2005) cited in Siller and Greefrath (2010), there are three groups of tools, namely: computational algebra systems (CAS), dynamic geometry software (DGS) and spreadsheet programs (SP). Those groups are present in most of the works reviewed.

In relation to the CAS, Perrenet and Adan (2010) showed that university students develop processes related to programming of algorithms; other works integrated this type of technology to parameterize data, perform operations and analyze graphs (Possani et al., 2010; Rodríguez Gallegos \& Quiroz Rivera, 2016; Trigueros, 2009). This type of technology allowed students to carry out processes of abstraction, concretization, analysis and synthesis. They also developed students' skills related to creativity and promoted the application and concretization of mathematical concepts, the definition of variables, the construction of assumptions in relation to problems, the analysis of graphs and the process of searching solutions to the situation under study. According to Geiger (2011), CAS and mathematical modeling provide a vision of the possibilities and obstacles that can be found when designing and implementing proposals that support the teaching of modeling through the use of digital technologies.

Regarding the DGS, this type of programs was used not only to solve geometric problems, but also to visualize graphics, validate models developed by students and study different mathematical concepts that emerge from animations and tables (Sekulić \& Takači, 2013; Stillman, 2011).

For the SP, studies show a use mainly for recording, organizing and analysis of data. For example, students organized a set of data to make dispersion diagrams and regressions when solving problems related to their tastes for music (Stillman \& Brown, 2014), or obtained average speeds when analyzing data intervals (Marshall \& Carrejo, 2008), or constructed representations to discuss, interpret or validate models (Daher \& Shahbari, 2015) or tabulated data from voltage sensors (Rodríguez \& Quiroz, 2016). A common characteristic in these works is the use of regressions as a means to find a model that fits the set of data analyzed.

The works presented up to now in this section reveal a particular trend in the use of digital technologies and a type of relationship between the characteristics of the device and the modeling processes. In the words of Geiger (2011), although technology can incorporate and generate representations that help in the transformation of an indeterminate situation to a certain one, it can also play a central role in reasoning. The development of this type of processes encourage students to solve problems, improve the use of a technological tool and approach in several ways the study of phenomena involving mathematics learning (Greefrath \& Vorhölter, 2016).

In this review, it was possible to establish that computer algebra programs were used specially to associate variables, analyze data, program and make graphs and animations. The dynamic geometry programs were used to recreate situations in a virtual environment and to appreciate the behavior of the phenomenon under study by altering some variables. This type of work approaches experimentation processes, although in some cases it does not manage to collect the minimum number of variables that affect the context of the phenomenon. Spreadsheets are useful for the organization and analysis of data, its representation through graphics and the possibility of assembling records obtained from sensors or calculators and systematizing them.

The development of modeling processes with programs such as Modellus shows the influence of digital technologies not only for the learning of mathematics, but also for the learning of natural science and other areas of knowledge. For example, in the work of Soares and Borba (2014), mathematics is integrated with biology so that participants can study the model of malaria transmission by focusing on graphics representation and identifying the variations of the phenomenon due to change of parameters and conditions. Molina-Toro (2013) showed how, through software simulation, students built ideas of variation, elaborated arguments and quantified movements and characteristics of the phenomena under study. In both works that used the Modellus software, the authors also emphasize that the students could not get by without the software, since it reorganized the activities of analyzing the model, using the graphic and numerical information and clarifying students' understanding of the phenomenon under study.

In particular, the last two mentioned works involve models and modeling activities articulated to a program that meets the conditions of being dynamic and having an interface that combines mathematical models with moving images and data tables. In addition, according to the didactic commitment of the teacher, the program allows to hide different tools of graphic information, algebraic models and other data so the teacher can propose its construction and, in this way, guide the type of processes performed by students.

The appearance and accessibility of Internet and mobile devices suggests another type of tool in addition to the three proposed by Barzel. Although mobile devices can integrate CAS, SP, DSG, they also involve APP, Applets, video games, simulations and video creation and analysis. These new tools offer opportunities for interaction and 
Table 3. Uses of digital technologies in modeling processes, reported in several studies Uses of digital technologies
in modeling processes Description

\section{Examples} Technology is a tool that the student uses for representative purposes and from the multiple

Visualization instrument representations obtained generates conjectures, arguments and ideas to approach or finish his

(Brown, 2015; Daher, 2015; Suárez Téllez \& modeling process.

\begin{tabular}{lll}
\hline $\begin{array}{l}\text { Instrument to simulate or } \\
\text { recreate phenomena }\end{array}$ & $\begin{array}{l}\text { Technology is used as a tool to discover the } \\
\text { behavior of a phenomenon, analyze numbers } \\
\text { and represent variables. }\end{array}$ & $\begin{array}{l}\text { (Alves \& de Souza Júnior, 2013; Pereira \& } \\
\text { Júnior, 2013; Frejd \& Ärlebäck, 2017; Krekic \& } \\
\text { Namestovski, 2009; Neves \& Teodoro, 2014) }\end{array}$ \\
\hline $\begin{array}{l}\text { Instrument to build and } \\
\text { validate models }\end{array}$ & $\begin{array}{l}\text { Technology is a tool that is linked to the process } \\
\text { of building a model or validating an existing one. }\end{array}$ & $\begin{array}{l}\text { (Dalla Vecchia \& Maltempi, 2012; Geiger, } \\
2011 \text { Stillman, 2011) }\end{array}$ \\
\hline $\begin{array}{l}\text { Instrument that reorganizes } \\
\text { experimentation processes }\end{array}$ & $\begin{array}{l}\text { Technology is used as a tool to discover the } \\
\text { behavior of a phenomenon, analyze numbers } \\
\text { and represent variables. }\end{array}$ & $\begin{array}{l}\text { (Molina-Toro, 2013; Ortega \& Puig, 2017; } \\
\text { Soares \& Borba, 2014) }\end{array}$ \\
\hline
\end{tabular}

collaboration between participants and, therefore, produce other forms of modeling and production of mathematical knowledge.

Mobile digital devices, such as cell phones or tablets, have also allowed to devise and to implement other modeling experiences with students. In a study presented by Frejd and Ärlebäck (2017) students used digital devices to interact with a game, record data that was represented in multiple ways and relate mathematical contents that emerged in the activity. In the same line, Ortega and Puig (2017) presented the development of an experience that integrated electronic tablets; using them, students could collect and process data of a phenomenon of free fall and thus choose a mathematical model from a family of functions. In both works, the influence of technology conditions the development of the process and is necessary for students to model the phenomenon under study.

As shown so far, there is a diversity of studies in which students, professors and technologies interact in modeling processes. Through these studies, it was possible to identify how multiple digital technologies are present throughout the modeling processes. Table 3 presents the uses of digital technologies in the development of modeling processes that were found in this review.

The characteristics of current technological devices offer also advantages for the recording of digital content and for the access to internet applications that give rise to new dynamics for the development of modeling processes. In this sense, the appearance of new programs determines the particular roles of digital technologies associated with their benefits for model construction, phenomena simulation and mediation in modeling processes (Greefrath, 2011).

This review shows that in modeling processes with technology, experiences can be developed to allow students to approach the study of mathematics in various ways through experimental practices. Some reflections about these facts are discussed in the following section.

\section{DISCUSSION AND CONCLUSIONS}

The scope and limitations of the articulation between modeling and digital technologies is a topic that continues to be open as new technologies appear and new research is developed regarding its inclusion in mathematics classroom. This review makes a contribution to the discussion about the characteristics of the environments that can be configured and the type of devices that can be used, as well as the different roles of technologies in modeling processes.

This study reveals two important findings. First, the roles that technologies play within the modeling processes. The literature has reported that technology supports various phases of these processes and recent work has made an effort to present the ways in which it takes part in a modeling cycle. Consistent with the above observation, this review contributes to the identification of two roles of technology as a result of different views on how to do modeling in the classroom. A first role was identified when technology is integrated as a resource in modeling processes; in this scenario, the vision of modeling represented through cycles is not altered, but it is observed that some actions of the participants are transformed and the analysis they make of the situation they study changes.

Technology provides other opportunities for students to experience each of the phases of the modeling process and therefore, new research that investigates how modeling cycles are configured using technological tools can be proposed for the future. Some theoretical advances in this line can be found in Greefrath, Hertleif and Siller (2018), Greefrath and Vorhölter (2016), Geiger (2011), Perrenet and Zwaneveld (2012), who identified how technology is used in the modeling cycle. 
Another role of technology was identified when it reorganized the dynamics of the modeling processes, that is, technology did not appear as a tool to solve a difficulty or facilitate a procedure, but as a means that allowed the development of the process and remained throughout it. In this sense, technology is not exclusively an available resource to those who model or design a modeling process, but seems to take a fundamental role through the process. This fact derives from theoretical conceptions in which technology is an extension of the thinking process of human beings and, therefore, stops having a utilitarian use to become a constitutive element of the student's action.

These findings evince that devices and programs that have been incorporated for several years in modeling processes in the classroom to obtain, process, represent and analyze data can now be performed with a unique technological tool. For example, the work of Ortega and Puig (2017) was developed with electronic tablets and applications, and the study by Frejd and Ärlebäck (2017) with a game that could be manipulated in various mobile devices. The role assumed by technology in those works transcends the use of the tool: technology becomes a necessary condition for the process to take place. Empirical data in Soares and Borba (2014) and Molina-Toro (2013) present similar studies in which the absence of technologies would change the characteristics of the results obtained.

A second finding was related to the multiple uses of technologies in modeling processes. The existing literature shows that, frequently, the technologies used in modeling processes are classified in CAS, DGS and SP. However, empirical studies analyzed in this review showed that there is a fourth group that extends this classification and determines other uses of tools in modeling processes.

According to literature reports, CAS, DGS and SP instruments have tools used to visualize the representation of data, make calculations, construct or validate models and simulate or recreate phenomena. As a contribution to the discussion in this line, this review found evidence of another group of instruments that gives meaning to a new category in which the experimentation processes are reorganized and other instruments, modified or designed from mobile devices, are incorporated.

The uses of technologies presented confirm the results of the study by Pereira et al. (2017) who found evidence of how computer programs allow access to different representations of mathematical objects, analysis and model building. However, in a broader view, this review presented four uses of technology that go beyond the identification of its benefits for data processing and related topics; this review recognizes a technology view that allows the possibility of transforming teaching and learning processes of mathematics. In that sense, the uses and roles of technology are not disjointed, but they could determine new ways of modeling.

A question emerges from these new ways of modeling and using mobile devices: in addition to the characteristics of the reviewed research works, if technology can reorganize experimentation processes, what influence can have the devices owned and used daily by students if used for modeling processes? This consideration serves to recognize the importance of technological tools owned by students in order to generate modeling environments that include certain experiences and interests of their contexts.

Students must harness the potential of technologies to have a transformational impact on what they do (Brown, 2015). Consistent with this premise, the use of mobile digital devices could become a resource that, in addition to making the most of all the possibilities offered by some electronic devices, serves sometimes as a substitute for computers or as a means to provide other alternatives for overcoming certain difficulties in the modeling processes. Some considerations in this regard have already been discussed by Villarreal, Esteley and Smith (2018) when analyzing the multiple needs that allow including technology in modeling processes. They presented a case where students had to learn to use spreadsheets or search the Internet for information in order to build a model.

As shown in this review, the articulation of modeling and technology allows to propose new challenges for the teaching and learning of mathematics and to build (Lingefjärd, 2012; Sekulić \& Takači, 2013; Soares \& Borba, 2014) experimentation scenarios that promote scientific competences (Bassanezi, 2002; Maas, 2007; Perrenet \& Adan, 2010). In this sense, this review contributes to the academic discussion on the continuous-change processes generated by technologies in the modeling processes and the opportunities it generates to promote the learning of mathematics.

Another implication emerges in relation to learning; It is necessary to broaden both theoretical and methodological approaches to establish the various ways in which mathematical knowledge is formed in modeling processes with digital technologies.

Although the analysis of empirical studies in this review found aspects of learning that relate to the resolution of problems, competences, abilities, experiments and processes of inquiry, there are still a need of studies that show how different conceptions of learning are reflected in different ways of approaching modeling with technologies in the classroom.

Finally, mobile devices, Internet, calculators and sensors, among others, are also constitutive tools for the development of modeling processes in the classroom (Borba et al., 2016; Soares \& Borba, 2014). In this sense, this 
review found that there is still a lack of studies that investigate how all the potentialities of these technological resources can be used to develop modeling processes and how the use of simulations that link modeling and technology could reinforce both teaching and learning processes of mathematics in different school grades. Authors such as Greefrath and Siller (2017), Greefrath and Vorhölter (2016) and Geiger (2011) have drawn attention in this regard and agree on the need to promote new studies.

Future studies could focus not only on multiple technological tools or student performances, but also on how they model, how they make sense of their conjectures, how they conduct their experiments, what is the impact of digital technologies on them and what are the characteristics of the tools they select to address those processes. Although the m-learning has presented some advances on these topics, the related literature is still scarce and, according to Frejd and Ärlebäck (2017), more theoretical and empirical research about the use of mobile devices in modeling is needed.

As mentioned above, although the contributions of the works on the articulation of digital technologies and modeling are recognized, their multiple possible configurations and the implied learning processes still remain a source of research and discussion.

\section{ACKNOWLEDGEMENTS}

We thank the group of professors and students of the Seminario Permanente of the Doctorate in Education of Universidad de Antioquia for their valuable contributions to this document. Our sense of gratitude with the doctoral scholarship program of COLCIENCIAS (announcement 7851) for the funding of the doctoral study that presents part of its findings in this article.

\section{REFERENCES}

Alves, D. B., \& de Souza Júnior, A. J. (2013). Mathematics Education in a Digital Culture. Journal of Mathematical Modelling and Aplication, 1(8), Retrieved 32-41. from http://gorila.furb.br/ojs/index.php/modelling/article/view/3354

Bassanezi, R. (2002). Ensino-Aprendizagem Com Modelagem Matemática: Uma Nova Estratégia. São Paulo: Contexto.

Blum, W. (2011). Can modelling be taught and learnt? Some answers from empirical research. In G. Kaiser, W. Blum, R. Borromeo Ferri, \& G. Stillman (Eds.), Trends in teaching and learning of mathematical modelling (pp. 15-30). Dordrecht: Springer. https://doi.org/10.1007/978-94-007-0910-2_3

Blum, W. (2015). Quality Teaching of Mathematical Modelling: What Do We Know, What Can We Do? In S. Cho (ed), The Proceedings of the 12th International Congress on Mathematical Education (pp. 73-96). Cham: Springer. https:/ / doi.org/10.1007/978-3-319-12688-3_9

Blum, W., \& Borromeo Ferri, R. (2009). Mathematical modelling: Can it be taught and learnt? Journal of Mathematical Modelling and Aplication, 1(1), 45-58. Retrieved from http://gorila.furb.br/ojs/index.php/modelling/article/view/1620

Blum, W., \& Leiss, D. (2007). How do Students and Teachers Deal with Modelling Problems? In C. Haines, P. Galbraith, W. Blum, \& S. Khan (eds) Mathematical Modelling: Education, Engineering and Economics-ICTMA 12 (pp. 222-231). Horwood: Chichester.

Blum, W., Galbraith, P., Henn, H. W., \& Niss, M. (Eds)(2007). Modelling and Applications in Mathematics Education. New York: Springer. https:/ / doi.org/10.1007/978-0-387-29822-1

Borba, M. C., Villarreal, M. E., \& Soares, D. S. (2016). Modeling using data available on the internet. In C. Hirsch \& E. McDuffie (Eds.), Mathematical modeling and modeling mathematics (pp. 143-152). Reston: National Council of Teacher of Mathematics.

Borba, M. de C., \& Villarreal, M. E. (2005). Humans-with-Media and the Reorganization of Mathematical Thinking. New York: Springer. https:/ / doi.org/10.1007/b105001

Brown, J. P. (2015). Visualisation Tactics for Solving Real World Tasks. In G. Stillman, W. Blum, \& M. S. Biembengut (Eds.), Mathematical Modelling in Education Research and Practice: Cultural, Social and Cognitive Influences (pp. 431-442). Cham: Springer. https:/ / doi.org/10.1007/978-3-319-18272-8_36

Buteau, C., Muller, E., Marshall, N., Sacristán, A. I., \& Mgombelo, J. (2016). Undergraduate Mathematics Students Appropriating Programming as a Tool for Modelling, Simulation, and Visualization: A Case Study. Digital Experiences in Mathematics Education, 2(2), 142-166. https:/ / doi.org/10.1007/s40751-016-0017-5

Campos, I. S., \& Araújo, J. L. (2015). Envolvimento dos Alunos em Atividades de Modelagem Matemática: relação com o saber e possibilidades de ação. Bolema: Boletim de Educação Matemática, 29(51), 167-182. https:/ / doi.org/10.1590/1980-4415v29n51a09 
Daher, W. M. (2015). Discursive positionings and emotions in modelling activities. International Journal of Mathematical Education in Science and Technology, 46(8), 1149-1164. https:/ / doi.org/10.1080/0020739X.2015.1031836

Daher, W. M., \& Shahbari, J. A. (2015). Pre-service teachers'modelling processes through engagement with model eliciting activities with a technological tool. International Journal of Science and Mathematics Education, 13(1), 25-46. https:// doi.org/10.1007/s10763-013-9464-2

Dalla Vecchia, R., \& Maltempi, M. V. (2012). Modelagem Matemática e Tecnologias de Informação e Comunicação: A realidade do mundo cibernético como um vetor de virtualização. Bolema: Boletim de Educação Matemática, 26(43), 963-990. https:/ / doi.org/10.1590/S0103-636X2012000300010

Diniz, L. N., \& Borba, M. C. (2012). Leitura e Interpretação de Dados Prontos em um Ambiente de Modelagem e Tecnologias Digitais: o mosaico em movimento. Bolema: Boletim de Educação Matemática, 26(43), $935-962$. https:/ / doi.org/10.1590/S0103-636X2012000300009

Frejd, P. (2013). Modes of modelling assessment-a literature review. Educational Studies in Mathematics, 84(3), 413438. https:// doi.org/10.1007/s10649-013-9491-5

Frejd, P., \& Ärlebäck, J. B. (2017). Initial Results of an Intervention Using a Mobile Game App to Simulate a Pandemic Outbreak. In G. Stillman, W. Blum, \& G. Kaiser (eds) Mathematical Modelling and Applications (pp. 517-527). Cham: Springer. https:// doi.org/10.1007/978-3-319-62968-1_43

Galbraith, P., Goos, M., Renshaw, P., \& Geiger, V. (2003). Technology Enriched Classrooms: Some Implications for Teaching Applications and Modelling. In Q.-X. Ye, W. Blum, K. Houston, \& Q.-Y. Jiang (Eds.), Mathematical Modelling in Education and Culture: ICTMA 10 (pp. 111-125). Chichester: Woodhead Publishing. https:/ / doi.org/10.1533/9780857099556.3.111

Geiger, V. (2011). Factors Affecting Teachers' Adoption of Innovative Practices with Technology and Mathematical Modelling. In G. Kaiser, W. Blum, R. Borromeo Ferri, \& G. Stillman (Eds.), Trends in Teaching and Learning of Mathematical Modelling: ICTMA14 (pp. 305-314). Dordrecht: Springer. https:/ / doi.org/10.1007/978-94-0070910-2_31

Greefrath, G. (2011). Using technologies: New possibilities of teaching and learning modelling-Overview. In G. Kaiser, W. Blum, R. Borromeo-Ferri, \& G. Stillman (Eds.), Trends in Teaching and Learning of Mathematical Modelling (pp. 301-304). Dordrecht: Springer. https://doi.org/10.1007/978-94-007-0910-2_30

Greefrath, G., \& Vorhölter, K. (2016). Teaching and Learning Mathematical Modelling: Approaches and Developments from German Speaking Countries. Cham: Springer. https:/ / doi.org/10.1007/978-3-319-45004-9

Greefrath, G., Hertleif, C., \& Siller, H.-S. (2018). Mathematical modelling with digital tools - A quantitative study on mathematising with dynamic geometry software. ZDM - Mathematics Education, 50(1-2), $233-244$. https:/ / doi.org/10.1007/s11858-018-0924-6

Greefrath, G., Siller, H.-S., \& Weitendorf, J. (2011). Modelling considering the influence of technology. In G. Kaiser, W. Blum, R. Borromeo Ferri, \& G. Stillman (Eds.)Trends in teaching and learning of mathematical modelling (pp. 315-329). Dordrecht: Springer. https:/ / doi.org/10.1007/978-94-007-0910-2_32

Jesson, J., \& Lacey, F. (2006). How to do (or not to do) a critical literature review. Pharmacy Education, 6(2), 139-148. https://doi.org/10.1080/15602210600616218

Kaiser, G. (2005). Mathematical modelling in school-Examples and experiences. In H.W. Henn \& G. Kaiser (Eds). Mathematikunterricht im Spannungsfeld von Evolution und Evaluation. Festband für Werner Blum (pp. 99-108). Hildesheim: Franzbecker.

Kaiser, G., \& Sriraman, B. (2006). A global survey of international perspectives on modelling in mathematics education. ZDM, 38(3), 302-310. https:/ / doi.org/10.1007/BF02652813

Krekic, V., \& Namestovski, Z. (2009). Computer modelling in mathematics education. In 2009 7th International Symposium on Intelligent Systems and Informatics (pp. 355-360). Subotica: IEEE. https://doi.org/10.1109/SISY.2009.5291132

Lingefjärd, T. (2012). Learning Mathematics through mathematical modelling. Journal of Mathematical Modelling and Application, 1(5), 41-49. Retrieved from http://gorila.furb.br/ojs/index.php/modelling/article/view/2896

Lingefjärd, T., \& Meier, S. (2010). Teachers as managers of the modelling process. Mathematics Education Research Journal, 22(2), 92-107. https:/ / doi.org/10.1007/BF03217568

Maas, K. (2007). Modelling in Class: What Do We Want the Students to Learn? In C. Haines, P. Galbraith, W. Blum, \& S. Khan (Eds.), Mathematical Modelling: Education, Engineering and Economics (ICTMA 12) (pp. 63-78). Chichester: Horwood Publishing. https:// doi.org/10.1533/9780857099419.2.63 
Marshall, J. A., \& Carrejo, D. J. (2008). Students' mathematical modeling of motion. Journal of Research in Science Teaching, 45(2), 153-173. https:/ / doi.org/10.1002/tea.20210

Molina-Toro, J. F. (2013). La modelación con tecnología en el estudio de la función seno. (Tesis de maestría no publicada). Universidad de Medellín.

Molina-Toro, J. F., \& Villa-Ochoa, J. A. (2013). La modelación con tecnología en el estudio de la función seno. Revista Científica, 2, 80-84. https:/ / doi.org/10.14483/23448350.5496

Neves, R. G., \& Teodoro, V. D. (2013). Computational modelling, interactive environments and science, technology, engineering and mathematics education [Modelação computacional, ambientes interactivos e o ensino da ciência, tecnologia, engenharia e matemática]. Revista Lusofona de Educacao, (25), 35-58. Retrieved from http:/ / www.scielo.mec.pt/scielo.php?script=sci_abstract\&pid=S1645-72502013000300004\&lng=es\&nrm=. $\mathrm{pf}$

Ortega, M., \& Puig, L. (2017). Using Modelling and Tablets in the Classroom to Learn Quadratic Functions. In G. Stillman, W. Blum, \& G. Kaiser (Eds.), Mathematical Modelling and Applications (pp. 565-575). Cham: Springer. https://doi.org/10.1007/978-3-319-62968-1_47

Parra-Zapata, M. M., \& Villa-Ochoa, J. A. (2016). Interacciones y contribuciones. Forma de participación de estudiantes de quinto grado en ambientes de modelación matemática. Actualidades Investigativas en Educación, 16(3), 1-27. https:/ / doi.org/10.15517/aie.v16i3.26084

Pereira, R. S. G., \& Júnior, S. (2013). Mathematical modeling and the teaching of adjustment function: a pedagogical handbook. Bolema: Boletim de Educação Matemática, 27(46), 531-546. https://doi.org/10.1590/S0103636X2013000300013

Pereira, R. S. G., Seki, J. T. P., Palharini, B., Neto, J. C., Silva, A. C., Damin, W., \& Martins, B. O. (2017). Modelagem matemática e tecnologias digitais educacionais: possibilidades e aproximações por meio de uma revisão sistemática de literatura. Revista de Ensino de Ciências e Matemática, 8(2), 80-94. Retrieved from http:/ / revistapos.cruzeirodosul.edu.br/index.php/rencima/article/view/1214

Perrenet, J., \& Adan, I. (2010). The academic merits of modelling in higher mathematics education: A case study. Mathematics Education Research Journal, 22(2), 121-140. https:/ / doi.org/10.1007/BF03217570

Perrenet, J., \& Zwaneveld, B. (2012). The many faces of the mathematical modeling cycle. Journal of Mathematical Modelling and Application, 1(6), 3-21. Retrieved from http://gorila.furb.br/ojs/index.php/modelling/ article/view/2815

Pons, M. O., \& Espinosa, L. P. (2015). Modelización de una situación real con tabletas: el experimento de la pelota. Modelling in Science Education and Learning, 8(2), 67-78. https:/ / doi.org/10.4995/msel.2015.3519

Possani, E., Trigueros, M., Preciado, J. G., \& Lozano, M. D. (2010). Use of models in the teaching of linear algebra. Linear Algebra and Its Applications, 432(8), 2125-2140. https:/ / doi.org/10.1016/j.laa.2009.05.004

Rendón-Mesa, P. A. (2016). Articulation between mathematics and the field of action of product design engineering: contributions of mathematical modeling [Articulación entre la matemática y el campo de acción de la ingeniería de diseño de producto: aportes de la modelación matemática] (Doctoral dissertation) (not published). Universidad de Antioquia. Medellín.

Rodríguez Gallegos, R., \& Quiroz Rivera, S. (2016). El rol de la experimentación en la modelación matemática. Educación Matemática, 28(3), 91-110. https:// doi.org/10.24844/EM2803.04

Sekulić, T., \& Takači, Đ. (2013). Mathematical modelling, computers and GeoGebra in university and college mathematics education. In 2013 36th International Convention on Information and Communication Technology, Electronics and Microelectronics (MIPRO) (pp. 625-630). Opatija: IEEE.

Siller, H.-S., \& Greefrath, G. (2010). Mathematical modelling in class regarding to technology. Siller, H. S., \& Greefrath, G. (2010). Mathematical modelling in class regarding to technology. In V. Durand-Guerrier, S. Soury-Lavergne \& F. Arzarello (Eds.), Proceedings of the sixth congress of the European Society for Research in Mathematics Education (pp. 2136-2145). Lyon: INRP.

Soares, D. da S., \& Borba, M. de C. (2014). The role of software Modellus in a teaching approach based on model analysis. ZDM - Mathematics Education, 46(4), 575-587. https:/ / doi.org/10.1007/s11858-013-0568-5

Stillman, G. (2011). Applying metacognitive knowledge and strategies in applications and modelling tasks at secondary school. In G. Kaiser, R. Borromeo Ferri, W. Blum, \& G. Stillman (Eds.), Trends in teaching and learning of mathematical modelling. ICTMA 14 (pp. 165-180). Dordrecht: Springer. https:// doi.org/10.1007/978-94-007-0910-2_18

Stillman, G., \& Brown, J. P. (2014). Evidence of implemented anticipation in mathematising by beginning modellers. Mathematics Education Research Journal, 26(4), 763-789. https:/ / doi.org/10.1007/s13394-014-0119-6 
Suárez Téllez, L., \& Cordero Osorio, F. (2008). Elementos teóricos para estudiar el uso de las gráficas en la modelación del cambio y de la variación en un ambiente tecnológico. Revista Electrónica de Investigación En Educación En Ciencias, 3(1), 51-58. Retrieved from http://www.scielo.org.ar/scielo.php?pid=S1850$66662008000100005 \&$ script $=$ sci_arttext\&tlng=en

Suárez Téllez, L., \& Cordero Osorio, F. (2010). Modelación-graficación, una categoría para la matemática escolar. Resultados de un estudio socioepistemológico. Revista Latinoamericana de Investigación En Matemática Educativa, 13(4-II), 319-333.

Trigueros, M. (2009). El uso de la modelación en la enseñanza de las matemáticas. Innovación Educativa, 9(46), 7587. Retrieved from https://www.redalyc.org/html/1794/179414894008/

Villa-Ochoa, J. A. (2007). La modelación como proceso en el aula de matemáticas, un marco de referencia y un ejemplo. Tecno Lógicas, 19, 63-85. https:/ / doi.org/10.22430/22565337.505

Villa-Ochoa, J. A., \& Berrío, M. J. (2015). Mathematical Modelling and Culture: An Empirical Study. In G. A. Stillman, W. Blum, \& M. S. Biembengut (Eds.), Mathematical Modelling in Education Research and Practice, International Perspectives on the Teaching and Learning (pp. 241-250). Cham: Springer. https:/ / doi.org/10.1007/978-3-319-18272-8_19

Villa-Ochoa, J. A., Castrillón-Yepes, A., \& Sánchez-Cardona, J. (2017). Types of modeling task for the mathematics class [Tipos de Tareas de Modelación para la clase de Matematica]. Espaço Plural, 18(36), 219-251.

Villa-Ochoa, J. A., González-Gómez, D., \& Carmona-Mesa, J. A. (2018). Modelling and technology in the study of the instantaneous rate of change in mathematics [Modelación y tecnología en el estudio de la tasa de variación instantánea en matemáticas]. Formación Universitaria, 11(2), 25-34. https:/ / doi.org/10.4067/S0718-50062018000200025

Villarreal, M. E., Esteley, C. B., \& Smith, S. (2018) Pre-service teachers' experiences within modelling scenarios enriched by digital technologies. ZDM - Mathematics Education 50(1-2), 327-341. https://doi.org/10.1007/s11858-018-0925-5

\section{http://www.ejmste.com}

